\title{
Degradation Kinetics and Characterization of Degradation Products of Losartan Potassium by LC-MS/MS method
}

\author{
Vladimir Dobričić, Bojan Marković* \\ University of Belgrade - Faculty of Pharmacy, Department of Pharmaceutical \\ Chemistry, Vojvode Stepe 450, 11221 Belgrade, Serbia \\ *Corresponding author. Tel: +381 11395134 , \\ e-mail: bojan.markovic@pharmacy.bg.ac.rs
}

\section{Summary}

This paper presents study of losartan potassium stability evaluation by liquid chromatography with UV/VIS and MS-MS detection and its degradation profile. A solution of losartan potassium was exposed to the following stress agents: $0.1 \mathrm{M} \mathrm{HCl}, 0.1 \mathrm{M} \mathrm{NaOH}$, and $3 \%(\mathrm{v} / \mathrm{v}) \mathrm{H}_{2} \mathrm{O}_{2}$. The analyses of losartan potassium solutions were carried out in a gradient elution mode with acetonitrile and $0.1 \%(\mathrm{v} / \mathrm{v}) \mathrm{CF}_{3} \mathrm{COOH}$ aqueous solution and constant flow rate of $0.5 \mathrm{~mL} \mathrm{~min}^{-1}$ within $22 \mathrm{~min}$ run time.

After 7 days of losartan potassium solutions exposure to the stress agents at room temperature, it was found that the degree of degradation in the presence of $0.1 \mathrm{M} \mathrm{HCl}$ and $0.1 \mathrm{M}$ $\mathrm{NaOH}$ was less than $1 \%$, while in the presence of $3 \% \mathrm{H}_{2} \mathrm{O}_{2}$ degradation was significantly higher (about 10\%). Chemical structure elucidation of the major degradation products of losartan potassium was performed using LC-MS/MS method.

The concentration versus time plot indicated that in $3 \%(\mathrm{v} / \mathrm{v}) \mathrm{H}_{2} \mathrm{O}_{2}$ solution losartan potassium was degraded according to the pseudo zero-order reaction kinetics with $1.48 \cdot 10^{-8} \mathrm{~mol}$ $\mathrm{L}^{-1}$ day $^{-1}$ rate constant.

Keywords: Losartan potassium; Forced degradation; Kinetics; LC-MS/MS 


\section{Introduction}

Angiotensin II receptor antagonists (ARA II) are used as the first line treatment in essential hypertension. ARA II have been developed to specifically and selectively block AT1 receptor of the rennin angiotensin system by displacing angiotensin II from it (1). Losartan potassium (potassium 5-[4'-[[2-butyl-4-chloro-5-(hydroxymethyl)-1Himidazol-1-yl]methyl]biphenyl-2-yl]tetrazol-1-ide) was the first antihypertensive drug that acts in accordance to this mechanism. It is effective agent for the treatment of hypertension and heart failure either alone or together with diuretics (2).

Forced degradation is crucial in providing useful information about the degradation pathways and degradation products that could be formed during manufacture and storage. The information thus obtained can facilitate pharmaceutical development in areas such as manufacturing, formulation development, synthesis of degradation products and packaging. Thus, stability testing is used to improve the quality of drug product (3).

The International Conference on Harmonization (ICH) makes a point of forced degradation study of drug substance to generate information on degradation products that can be formed under the influence of hydrolytic, oxidative, thermal or photolytic degradation conditions. ICH defines procedure for the photolytic degradation investigations, whereas for other stress conditions only recommendations are provided. Registration documentation of new drug requires data of forced degradation studies, including degradation products, degradation reaction kinetics, structure, mass balance, chromatographic peak purity, etc $(4,5)$.

Several methods have been published for simultaneous determination of ARA II drugs in the presence of the degradation products, including UV spectrophotometry (6, 7), $\operatorname{HPTLC}(8,9) \operatorname{HPLC}(10-13)$ HPLC-MS and HPLC-MS/MS $(14,15)$, as well as multidimensional NMR and FTIR (16).

The aim of this paper was to characterize the forced degradation products of losartan potassium by LC-MS/MS method, as well as to determine chemical degradation reaction kinetics under stress conditions.

\section{Experimental}

\subsection{Chemicals and reagents}

Losartan potassium working standard powder was kindly supplied by pharmaceutical company PharmaS (Serbia). All of the reagents used in the experiment were of analytical grade. Hydrochloric acid (Centrohem, Serbia), sodium hydroxide (Centrohem, Serbia), 30\% (v/v) hydrogen peroxide (Centrohem, Serbia) and methanol HPLC grade (Macron fine chemicals, Poland) were used for the preparation of the solutions. Ultra-pure water (purified by the TKA GenPure system, Germany), 
trifluoroacetic acid for HPLC (Merck, Germany) and acetonitrile LC/MS grade (SigmaAldrich, Germany) were used for the preparation of the mobile phase.

\subsection{Instrumentation}

Analyses were carried out on a UHPLC-MS/MS system consisting of a Thermo ACCELA UHPLC (Thermo Scientific, Waltham, MA, USA) equipped with PDA detector and coupled to Thermo TSQ Quantum Access Max triple quad Mass Spectrometer (Thermo Scientific, Waltham, MA, USA) with a heated electrospray ionization (HESI) interface. A $20 \mu \mathrm{L}$ samples were injected into a Waters Xterra ${ }^{\circledR} \mathrm{MS}$ C18 column $(3.5 \mu \mathrm{m}, 150 \mathrm{~mm} \times 2.1 \mathrm{~mm})$ and eluted with $500 \mu \mathrm{L} \mathrm{min}{ }^{-1}$ mobile phase flow rate (column temperature was set to $25^{\circ} \mathrm{C}$ ). The mobile phase was filtered through a $0.22 \mu \mathrm{m}$ nylon filter before use and consisted of solution A (acetonitrile) and solution B $\left(0.1 \%(\mathrm{v} / \mathrm{v}) \mathrm{CF}_{3} \mathrm{COOH}\right.$ aqueous solution), with a timed gradient mode $\mathrm{T}(\mathrm{min}) / \% \mathrm{~A}$ : $0 \mathrm{~min} / 20 \%, 1 \mathrm{~min} / 20 \%, 20 \mathrm{~min} / 80 \%$, $20.5 \mathrm{~min} / 80 \%, 21 \mathrm{~min} / 20 \%, 22 \mathrm{~min} / 20 \%$.

PDA detection was carried out at $220 \mathrm{~nm}$. MS analysis was performed in a positive-ion mode. The spectrometer was optimized by infusion of losartan potassium working standard solution in methanol $(10 \mathrm{ppm})$, using the integrated syringe pump (flow rate $10 \mu \mathrm{L} \mathrm{min}{ }^{-1}$ ). The spray voltage was $5000 \mathrm{~V}$. The temperature in the capillary was adjusted to $200{ }^{\circ} \mathrm{C}$, while the vaporizer temperature was set to $200{ }^{\circ} \mathrm{C}$. Sheet gas pressure was set to 40 units, while the auxiliary valve flow was set to 15 units. MS resolution values were defined to correspond to a mass resolution of $0.7 \mathrm{Da}$. All data were acquired and processed by Xcalibur software (ThermoFisher, SanJose, CA, USA).

\subsection{Sample preparation}

To prepare the stock solution $\left(\mathrm{c}=10 \mathrm{mg} \mathrm{mL}^{-1}\right), 500 \mathrm{mg}$ of losartan potassium working standard was accurately weighted into a $50 \mathrm{~mL}$ volumetric flask, dissolved in methanol and filled up to volume. Working solutions were obtained by diluting $5 \mathrm{ml}$ stock solution in five $50 \mathrm{~mL}$ volumetric flasks and filled up to volume with $0.1 \mathrm{M} \mathrm{HCl}$, $0.1 \mathrm{M} \mathrm{NaOH}, 3 \%(\mathrm{v} / \mathrm{v}) \mathrm{H}_{2} \mathrm{O}_{2}$, water and methanol, respectively. Final solutions were prepared by diluting $2.5 \mathrm{~mL}$ of corresponding working solutions with methanol in $5 \mathrm{~mL}$ volumetric flasks immediately before injection. Concentrations of these solutions were $0.5 \mathrm{mg} \mathrm{mL}^{-1}$.

\subsection{Analysis of degradation products}

Prepared solutions were kept at room temperature and analysis of degradation products was performed after seven days. For identification of main degradation products, LC-MS chromatograms were recorded in full scan mode with $\mathrm{m} / \mathrm{z}$ ratios in the range from 210 to 1000 . For all of identified degradation product, MS/MS spectra were recorded by direct infusion of analyzed solution in spectrometer. The obtained fragment ions were used for structural analysis. 


\subsection{Kinetics of chemical degradation}

Degradation of losartan potassium was monitored 3.5 months under selected conditions by LC-MS simple ion monitoring (SIM) acquisition. Quantification of the remaining losartan potassium in the analyzed solutions was performed by monitoring losartan $[\mathrm{M}+\mathrm{H}]^{+}$ion $(\mathrm{m} / \mathrm{z}) 423$ and by comparing with chromatographic peaks from chromatogram of standard solution (zero-time solution).

\section{Results and discussion}

According to the literature data, losartan showed lower degradation under thermal and photolytic stress conditions in comparison to some other cardiovascular drugs, such as valsartan and ramipril $(17,18)$. In this study, stability of losartan potassium in $0.1 \mathrm{M}$ $\mathrm{HCl}, 0.1 \mathrm{M} \mathrm{NaOH}$ and $3 \%(\mathrm{v} / \mathrm{v}) \mathrm{H}_{2} \mathrm{O}_{2}$ solutions was preliminary investigated Seven days after the preparation of solutions, LC analysis with PDA and MS/MS detector was carried out. Amounts of degraded losartan potassium in solutions of $0.1 \mathrm{M} \mathrm{HCl}$ and 0.1 $\mathrm{M} \mathrm{NaOH}$ were under $1 \%$. The quantity of decomposed losartan potassium in $3 \%(\mathrm{v} / \mathrm{v})$ $\mathrm{H}_{2} \mathrm{O}_{2}$ solution was about $10 \%$ and this sample was used for the following analysis. A large number of degradation products was detected as a result of oxidation process (Fig. 1).

Losartan showed $[\mathrm{M}+\mathrm{H}]^{+}$peaks at $\mathrm{m} / \mathrm{z} 423$ and 425 with a $3: 1$ relative intensity ratio, as expected for a molecule containing one chlorine atom. Five fragment ions were identified in MS/MS spectrum, which has already been reported (m/z 377, 341, 235, 207 and 192) (14). These fragment ions should provide the base pattern for the identification of degradation products.

The predominant degradation product of losartan potassium (LD-6) was formed by oxidation of primary alcohol group to aldehyde (Fig. 2). Retention time of LD-6 $(\mathrm{m} / \mathrm{z} 421)$ was $12.73 \mathrm{~min}$. Characteristic fragment ions of losartan were found in MS/MS spectrum of LD-6, with the most abundant m/z 207 fragment ion. LD-3 was formed by subsequent aromatic hydroxylation of LD-6, with $\mathrm{m} / \mathrm{z} 437$ and $8.39 \mathrm{~min}$ retention time. Degradation product LD-5 (m/z 437) was formed from LD-6 by oxidation of aldehyde to carboxylic group (retention time was 10.58). Some degradation products, marked as LD-4 (m/z 439), are structural isomers produced by oxidation of biphenyl rings of losartan in different positions (retention times $8.66 \mathrm{~min}, 9.31 \mathrm{~min}$, $10.15 \mathrm{~min}$ and $12.14 \mathrm{~min}$ ). 


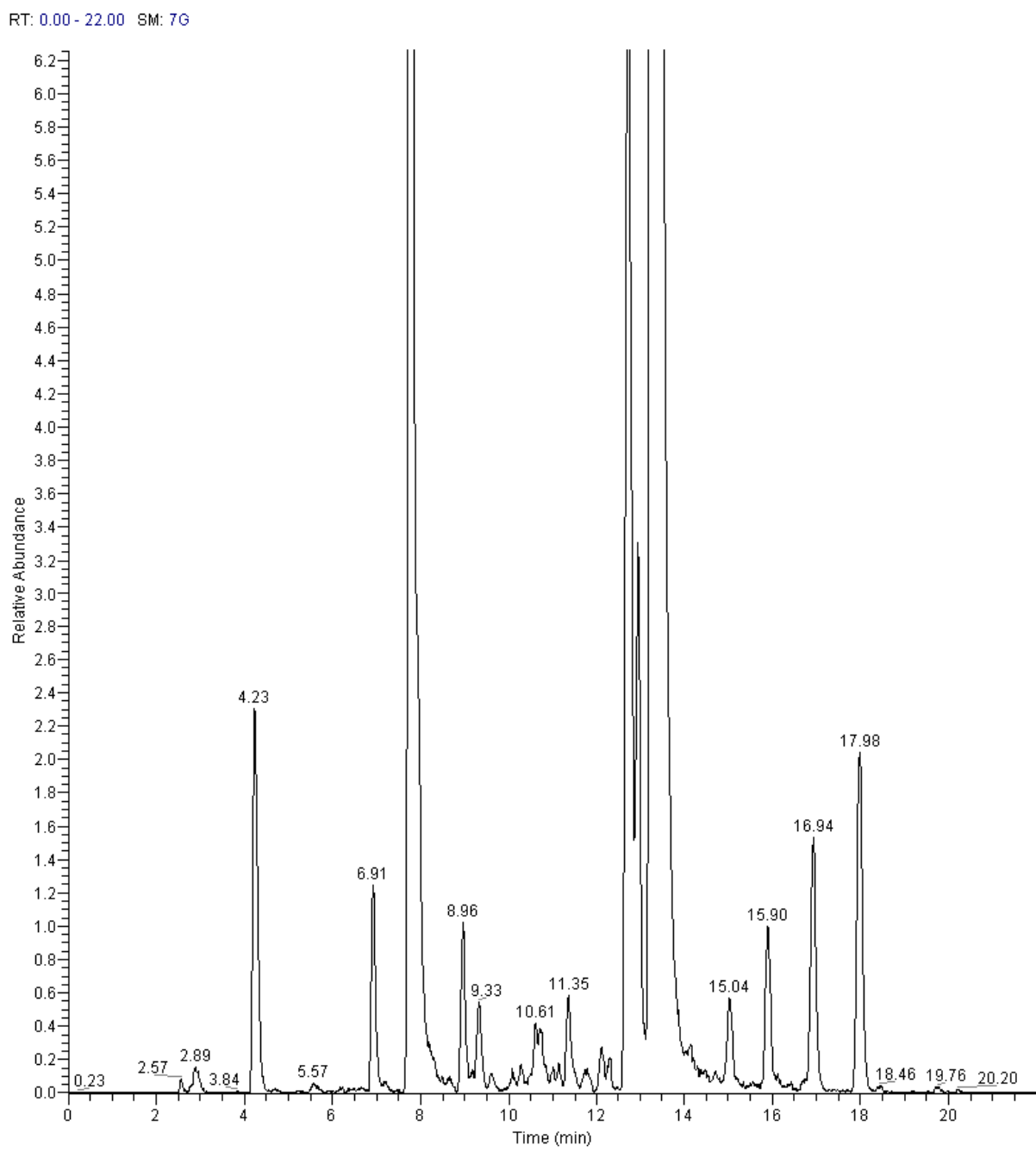

NL: $2.08 \mathrm{E} 8$

TIC F: + c ESI Full pr

207.000

[210.000-1000.000] MS

29_04_2015_Losartan

H2O2_Metoda_15_Prob

a_1

Figure 1. LC-MS chromatogram (TIC) of losartan potassium solution in $3 \%(\mathrm{v} / \mathrm{v}) \mathrm{H}_{2} \mathrm{O}_{2}$ after 7 days exposure.

Slika 1. LC-MS hromatogram (TIC) rastvora losartan kalijuma u $3 \%$ (v/v) $\mathrm{H}_{2} \mathrm{O}_{2}$ nakon 7 dana izlaganja.

The degradation products LD-1 (m/z 252, retention time $4.26 \mathrm{~min})$ and LD-2 (m/z 335 , retention time $7.77 \mathrm{~min}$ ) were generated by the destruction of imidazole rings in which an unstable 2,5-endoperoxide was formed in reaction of 1,4-cycloaddition of molecular oxygen $(14,19)$.

Different degradation products in dimeric form could be produced. Oxidation of benzene ring in one monomer unit gives LD-10 with $\mathrm{m} / \mathrm{z} 881$ at retention time of 18.06 min. If primary alcohol group in only one monomer unit of dimer oxidized to aldehyde, LD-7 was formed ( $\mathrm{m} / \mathrm{z} 864$, retention time $13.38 \mathrm{~min})$, while subsequent oxidation of 
biphenyl rings gave LD-9 (m/z 879, retention time $15.89 \mathrm{~min})$. Degradation product LD-8 was formed by oxidation of primary alcohol group to carboxylic acid only in one monomer unit ( $\mathrm{m} / \mathrm{z} 841$, retention time $15.02 \mathrm{~min})$.

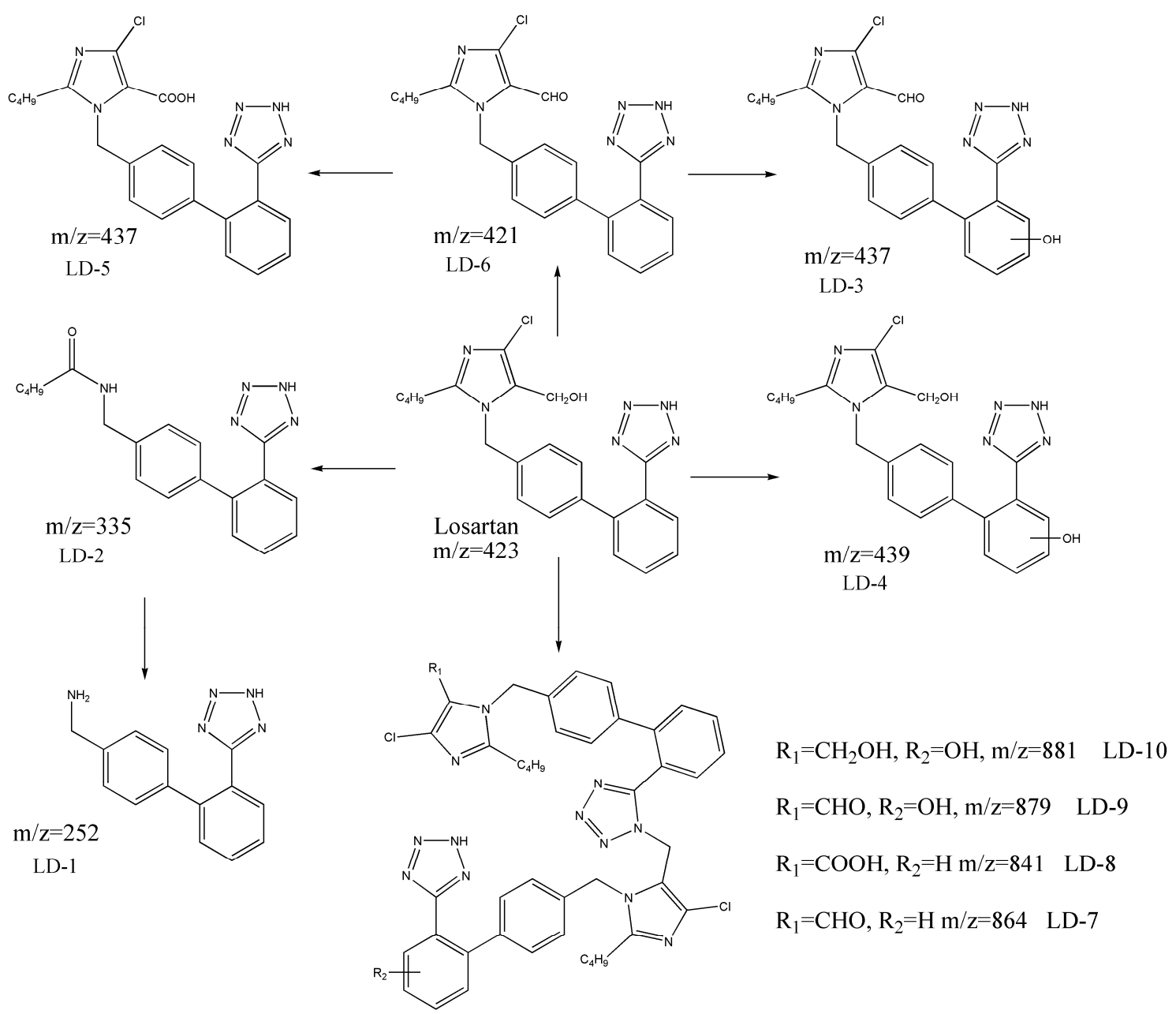

Figure 2. Structures of degradation products of losartan potassium in $3 \%(v / v) \mathrm{H}_{2} \mathrm{O}_{2}$ solution.

Slika 2. Strukture degradacionih proizvoda losartan kalijuma u rastvoru $3 \%$ (v/v) $\mathrm{H}_{2} \mathrm{O}_{2}$.

In MS/MS spectra, all dimer degradation products with primary alcohol group had fragment ion $\mathrm{m} / \mathrm{z} 423$, dimer degradation products with aldehyde group had fragment ion $\mathrm{m} / \mathrm{z} 421$ and dimer degradation products with aldehyde group had fragment ion $\mathrm{m} / \mathrm{z}$ 437.

The reaction of dimerization is $\mathrm{SN}_{2}$ type nucleophilic substitution, where alcohol group of the first monomer unit reacts with $\mathrm{NH}$ of imidazole ring of the second unit (14). 
The degradation process of losartan potassium in $3 \%(\mathrm{v} / \mathrm{v}) \mathrm{H}_{2} \mathrm{O}_{2}$ solution was monitored during about 3.5 months at the room temperature. The graph of the remaining concentration of losartan potassium versus time was created (Fig. 3), rate constant and order of reaction were determined by graphical method. Due to the linear decrease in losartan potassium concentration and due to the excess of $3 \%(\mathrm{v} / \mathrm{v}) \mathrm{H}_{2} \mathrm{O}_{2}$ used in this study, it can be concluded that losartan potassium was decomposed by pseudo zeroorder kinetics $\left(1.48 \cdot 10^{-8} \mathrm{~mol} \mathrm{~L}^{-1}\right.$ day $^{-1}$ rate constant). After 3.5 months, the amount of remaining losartan potassium in $3 \%(\mathrm{v} / \mathrm{v}) \mathrm{H}_{2} \mathrm{O}_{2}$ solution was below $25 \%$. Since losartan potassium is susceptible to oxidation, during the drug product manufacturing it is important to pay attention to the selection of packing material and excipients, particularly to those that could contain peroxide impurities.

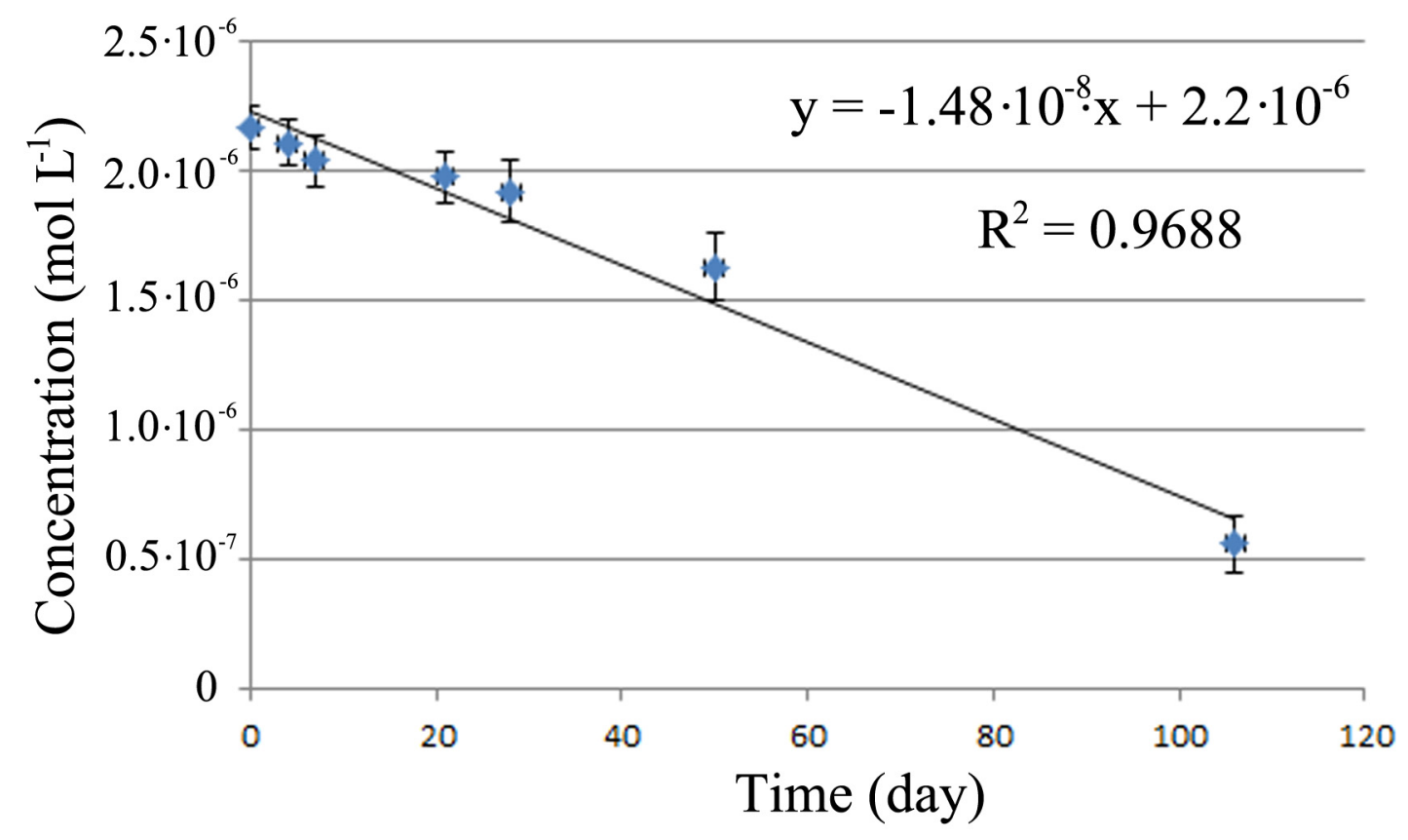

Figure 3. Pseudo zero-order oxidative degradation of losartan potassium in $3 \%(\mathrm{v} / \mathrm{v}) \mathrm{H}_{2} \mathrm{O}_{2}$ solution.

Slika 3. Kinetika pseudo nultog reda reakcije oksidativne degradacije losartan kalijuma u rastvoru $3 \%(v / v) \mathrm{H}_{2} \mathrm{O}_{2}$.

\section{Conclusion}

Significant appearance of degradation products during stability investigation of losartan potassium was observed in the solution of $3 \%(\mathrm{v} / \mathrm{v}) \mathrm{H}_{2} \mathrm{O}_{2}$ seven days after 
exposure. In this solution, degradation products were formed by oxidation of primary alcohol group, hydroxylation of benzene ring and dimerization.

Quantification of the remaining losartan potassium in the solution exposed to 3\% (v/v) $\mathrm{H}_{2} \mathrm{O}_{2}$ and the application of graphical method indicated that the degradation process followed pseudo zero-order reaction kinetics with $1.48 \cdot 10^{-8} \mathrm{~mol} \mathrm{~L}^{-1}$ day $^{-1}$ rate constant.

\section{Acknowledgement}

This work was partly supported by the Ministry of Education and Science, Belgrade, Serbia, as a part of Project No. OI172041 and TR34031.

\section{Literature}

1. Mycek MJ, Illustrated Reviews Pharmacology, second edition, Lippincott Williams\&Wilkins, Pennsylvania, USA, 2000, pp. 179-187

2. Katzung BG. Basic and Clinical Pharmacology, tenth edition, McGraw-Hill, Singapore, 2007, pp. 159-177

3. Ibrahim MM, Hegazy MA, Abd El-Ghani MA. Application of a RP-HPLC method for comparative study on the degradation behavior of two angiotensin ii receptor antagonists, valsartan and losartan potassium. International Journal of Pharmaceutical, Chemical \& Biological Sciences. (2015);5(2):417-26

4. International Conference on Harmonisation of Technical Requirements for Registration of Pharmaceuticals for Human Use, ICH Harmonised Tripartite Guideline: Stability Testing of New Drug Substances and Products Q1A (R2), Step 5, ICH Geneva, Aug. 2003.

5. Jain D, Basniwal PK. Forced degradation and impurity profiling: recent trends in analytical perspectives. Journal of pharmaceutical and biomedical analysis. (2013);86: 11-35.

6. Rathee P, Rathee1 S, Chaudhary1 H, Dharmender Rathee D. Development and validation of a stability indicating UV-spectrophotometric method for the estimation of losartan potassium in bulk and tablet dosage form. Journal of Pharmacy Research (2008);1(2):188-92.

7. Rathee P, Ratheea S, Ratheeb D, Chaudharya H. Stability Indicating UV-Spectrophotometric Methods for Simultaneous Determination of Losartan Potassium and Hydrochlorothiazide in Pharmaceuticals. Euroasian journal of analytical chemistry. (2009);4(1):98-109.

8. El-Shaboury SR, Hussein SA, Mohamed NA, El-Sutohy MM. Stability-Indicating Densitometric Determination of Some Angiotensin II Receptor Antagonists in Presence of Their Degradation Products. Acta Chromatographica. (2013);25(1):79-95. 
9. McCarthy KE, Wang Q, Tsai EW, Gilbert RE, Ip DP, Brooks MA. Determination of losartan and its degradates in $\mathrm{COZAAR}^{\circledR}$ tablets by reversed-phase high-performance thin-layer chromatography. Journal of Pharmaceutical and Biomedical Analysis (1998); 17: 671-7.

10. Elshanawane AA, Abdelaziz LM, Hafez HM Stability Indicating HPLC Method for Simultaneous Determination of Several Angiotensin-II Receptor Antagonists in Their Dosage Forms. Pharmaceut Anal Acta. (2012); 3:175.

11. Ibrahim MM, Hegazy MA, Abd El-Ghani MA. Application of a RP-HPLC method for comparative study on the degradation behavior of two angiotensin II receptor antagonists, valsartan and losartan potassium. International journal of pharmaceutical, chemical and biological sciences. (2015);5(2): 417-26.

12. Qiu S, Liu K, Ma P, Wang M, Chen H, Xu X, Hao X, Wang Y. Simultaneous analysis of losartan potassium and its related impurities and degradation products in tablets using HPLC. Current Pharmaceutical Analysis (2015); 11:25-34.

13. Lusina M, Cindrić T, Tomaić J, Peko M, Pozaić L, Musulin N. Stability study of losartan/hydrochlorothiazide tablets. International journal of pharmaceutics. (2005); 291:127-37.

14. Zhao ZZ, Wang Q, Tsai EW, Qin XZ, Ip D. Identification of losartan degradates in stressed tablets by LC-MS and LC-MS/MS. Journal of pharmaceutical and biomedical analysis. (1999); 20(12):129-36.

15. Thapa M, Nautiyal R, Datar M, Singh AK. Isolation, Identification and Caracterization of Process Related Impurities in Losartan Potassium Drug Substance. Asian Journal of Chemistry (2010); 22(6):4295-98.

16. Pandey AK, Rapolu R, Raju CK, Sasalamari G, Goud SK, Awasthi A, Navalgund SG, Surendranath KV. The novel acid degradation products of losartan: Isolation and characterization using Q-TOF, 2D-NMR and FTIR Journal of Pharmaceutical and Biomedical Analysis. (2016); 120:65-71.

17. Kollipara S, Bende G, Bansal Y, Saha R. Stability-indicating reversed-phase liquid chromatographic method for simultaneous determination of losartan potassium and ramipril in tablets. Indian journal of pharmaceutical sciences. (2012); 74:201-210

18. Ibrahim MM. Investigation on thermal stability and purity determination of two antihypertensive drugs, valsartan and losartan potassium. International Journal of Current Pharmaceutical Research (2015);7:64-69.

19. Seburg RA, Ballard JM, Hwang TL, Sullivan CM. Photosensitized degradation of losartan potassium in an extemporaneous suspension formulation. Journal of Pharmaceutical and Biomedical Analysis (2006); 42:411-22. 


\title{
Kinetika Degradacije i Karakterizacija Degradacionih Proizvoda Losartan Kalijuma LC- MS/MS metodom
}

\author{
Vladimir Dobričić, Bojan Marković* \\ Univerzitet u Beogradu - Farmaceutski fakultet, Katedra za farmaceutsku hemiju, \\ Vojvode Stepe 450, 11221 Beograd, Srbija \\ *Autor za korespondenciju. Tel: +381 113951341 , \\ e-mail: bojan.markovic@pharmacy.bg.ac.rs
}

\section{Kratak sadržaj}

U ovom radu opisano je ispitivanje stabilnosti losartan kalijuma primenom tečne hromatografije sa UV i MS-MS detekcijom i prikazan je njegov profil degradacionih proizvoda. Rastvor losartan kalijuma bio je izložen dejstvu sledećih stres agenasa: 0,1 M HCl; $0,1 \mathrm{M} \mathrm{NaOH}$ i 3\% (v/v) $\mathrm{H}_{2} \mathrm{O}_{2}$. Rastvori losartan kalijuma analizirani su gradijentnim eluiranjem sa acetonitrilom i $0,1 \%(\mathrm{v} / \mathrm{v})$ vodenim rastvorom $\mathrm{CF}_{3} \mathrm{COOH}$ pri konstantnom protoku od $0,5 \mathrm{ml} \mathrm{min}^{-1}$ i vremenom trajanja od $22 \mathrm{~min}$.

Degradacija u rastvorima losartan kalijuma koji su 7 dana bili izloženi dejstvu $0,1 \mathrm{M} \mathrm{HCl}$ i $0,1 \mathrm{M} \mathrm{NaOH}$ bila je manja od $1 \%$, dok je u prisustvu $3 \%$ (v/v) $\mathrm{H}_{2} \mathrm{O}_{2}$ bila značajno veća (oko $10 \%$ ). Identifikacija i strukturna analiza glavnih degradacionih proizvoda losartan kalijuma izvršena je primenom LC-MS/MS metode.

Grafička zavisnost izmerenih koncentracija u funkciji vremena ukazuje da se losartan kalijum u rastvoru $3 \%(\mathrm{v} / \mathrm{v}) \mathrm{H}_{2} \mathrm{O}_{2}$ degradira kinetikom pseudo nultog reda sa konstantnom brzine reakcije od $1.48 \cdot 10^{-8} \mathrm{~mol} \mathrm{~L}^{-1} \mathrm{dan}^{-1}$.

Ključne reči: Losartan kalijum; Forsirana degradacija; Kinetika; LC-MS/MS 